\title{
Management of the patient with persistent symptoms after COVID-19 in primary care
}

\author{
Managementul pacientului cu simptomatologie persistentă postCOVID-19 în \\ asistența medicală primară
}

\author{
Mihaela Adela IANCU ${ }^{1,2}$, Laura Maria CONDUR ${ }^{3}$, Irina EREMIA ${ }^{1,4}$, Adriana TICĂRĂU ${ }^{1,2}$, \\ Camelia Cristina DIACONU ${ }^{1,5}$, Dumitru MATEI ${ }^{1,6}$ \\ ${ }^{1}$ Universitatea de Medicină și Farmacie „Carol Davila“, București, România \\ ${ }^{2}$ Cabinet medical individual, București, România \\ ${ }^{3}$ Facultatea de Medicină, Universitatea „Ovidius“, Constanța, România \\ ${ }^{4}$ Spitalul Universitar de Urgență, București, România \\ ${ }^{5}$ Spitalul Clinic de Urgență, București, România \\ ${ }^{6}$ Institutul Național pentru Sănătatea Mamei și Copilului „Alessandrescu-Rusescu“, București, România
}

\begin{abstract}
After the acute period of the infection with SARS-CoV-2, new symptoms may appear. Alternatively, those present might persist. Medium-term symptoms and complications of COVID-19 infection have been reported to persist in several organs such as the heart, lungs, liver, kidneys, and brain. Subsequent monitoring varies from one week to three months, depending on the symptoms and risk factors present. During the initial follow-up assessment, a comprehensive history of the patient's COVID-19 disease, including disease history, duration and severity of symptoms, types and severity of complications has to be obtained. The need for laboratory tests is determined by the severity of the disease, previous results during their illness and current symptoms.
\end{abstract}

Keywords: SARS-CoV-2, general practitioner, ongoing symptomatic, post-COVID-19

\begin{abstract}
REZUMAT
După perioada acută a infecției cu virusul SARS-CoV-2, pot apărea simptome noi sau vor persista cele prezente. Au fost raportate simptome și complicații pe termen mediu ale infecției COVID-19 asupra mai multor organe precum cordul, plămânii, ficatul, rinichii, creierul. Monitorizarea ulterioară variază de la o săptămână până la trei luni, în funcție de simptomatologia și factorii de risc prezenți. În timpul evaluării inițiale de urmărire, obținem un istoric cuprinzător al bolii COVID-19 a pacientului, incluzând cronologia bolii, durata și severitatea simptomelor, tipurile și severitatea complicațiilor. Necesitatea testelor de laborator este determinată de severitatea bolii, de rezultatele anterioare în timpul bolii și de simptomele actuale.
\end{abstract}

Cuvinte cheie: SARS-CoV-2, medic de familie, simptomatic persistent, postCOVID-19 


\section{DEFINIṬII, CLASIFICARE}

Pacienții infectați cu noul coronavirus prezintă afectarea pulmonară și extrapulmonară [1,2]. Majoritatea persoanelor infectate cu virusul SARS-CoV-2 vor avea afectare respiratorie ușoară până la moderată și se vor recupera fără a necesita tratament special. Pacienții cu probleme medicale subiacente, cum ar fi bolile cardiovasculare, diabetul zaharat, bolile respiratorii cronice și cancerul, sunt mai susceptibile de a dezvolta o formă severă de boală $[1,2]$.

Conform British National Institute for Health and Care Excellence (NICE), putem clasifica infecția cu virusul SARS-CoV2-2 din punct de vedere evolutiv în trei etape:

- COVID-19 acut - Infecția acută cu virusul SARSCoV-2 - atunci când semnele și simptomele sunt prezente în primele 4 săptămâni de la debutul clinic;

- Infecția cu virusul SARS-CoV-2 simptomatică persistentă, semnele și simptomele sunt prezente după 4 săptămâni, dar nu mai târziu de 12 săptămâni după debutul clinic sau primul test RT-PCR pozitiv;

- Sindromul postCOVID-19, atunci când semnele și simptomele sunt prezente după 12 sau mai multe săptămâni de la debutul clinic sau primul test RT-PCR pozitiv [3].

\section{CARACTERISTICI CLINICE}

Boala denumită COVID-19 sau sindromul respirator acut sever este determinată de noul coronavirus, SARS-CoV-2. Au fost descrise forme asimptomatice, mai frecvent întâlnite la copii și tineri, și forme clinice, cu severitate variabilă, având afectare pulmonară, dar și extrapulmonară: miocardică, hepatică, renală, neurologică, cutanată, însoțită de afectare vasculară și hipercoagulabilitate [4-6].

Se estimează că cel puțin o treime dintre infecțiile cu SARS-CoV-2 sunt asimptomatice. Studiile longitudinale au arătat că aproape trei sferturi dintre persoanele care primesc un rezultat pozitiv al testului PCR, dar care nu prezintă simptome în momentul testării, vor rămâne asimptomatice și la două săptămâni de la testare [7]. Având în vedere prevalența infecțiilor asimptomatice, precum și riscul de transmitere a infecției asimptomatice cu SARS-CoV-2, s-a propus schimbarea strategiilor de control pentru COVID-19; masca individuală, igiena mâinilor, distanțarea socială au stat la baza măsurilor preventive [7]. De remarcat faptul că definiția pacientului asimptomatic diferă în diferitele studii raportate, în funcție de simptomele evaluate. Simptomatologia infecției cu virusul SARS-CoV-2 fiind extrem de variată, de la febră, frisoane, tuse, dificultăți în respirație, dureri toracice, anosmie, ageuzie, la simptome digestive (greață, vărsături, diaree, dureri abdominal), simptome generale (oboseală extremă, scădere ponderală, anorexie), precum și mialgie, artralgie $[8,9,10]$.

Simptomatologia prezentă în perioada acută a infecției cu SARS-CoV-2, într-un lot de peste 370.000 de cazuri confirmate de COVID-19, a fost următoarea: tuse prezentă în $50 \%$ dintre cazuri încă de la debut, febra subiectivă sau cu valori obiectivate $>38^{\circ} \mathrm{C}$ a fost înregistrată în 43\% dintre cazuri, mialgie în 36\% dintre cazuri, cefalee în $34 \%$ dintre cazuri - de cele mai multe ori cu intensitate medie spre severă, dispnee în 29 \% dintre cazuri, disfagie aproape într-o cincime de pacienți, diaree în 19\% dintre cazuri, greață/vărsături în 12\% dintre cazuri. Pierderea parțială sau totală a mirosului sau a gustului, durerile abdominale și rinoreea au fost prezente în mai puțin de $10 \%$ dintre cazuri [11].

În alte studii publicate, tulburările de miros și gust (anosmia și disgeuzia) au fost raportate mai frecvent. Într-o metaanaliză a zece studii observaționale, estimările de prevalență combinate pentru anomalii ale mirosului sau ale gustului au fost de $52 \%$ și, respectiv, $44 \%$ (deși prevalența tulburărilor de miros și gust a variat de la 5 la 98\% între studii) [12]. În unele studii observaționale, ar fi de remarcat faptul că prevalența anosmiei sau a anomaliilor gustative raportate poate fi mai mică în realitate decât prevalența autoraportată. Într-un alt studiu, 38\% dintre cei 86 de pacienți care au raportat anosmia la momentul evaluării aveau o funcție normală a mirosului la testarea obiectivă [13]. Cele mai multe tulburări subiective ale mirosului și gustului asociate cu COVID-19 nu par a fi permanente; într-un studiu ce a urmărit 202 pacienți cu COVID-19, 89\% dintre cei care au observat modificări ale mirosului sau ale gustului au raportat revenirea la normal sau îmbunătățirea la patru săptămâni de la debut [14].

\section{MANAGEMENTUL PACIENTULUI CU SIMPTOMATOLOGIE PERSISTENTĂ}

Ulterior, cele mai frecvente simptome ce au persistat peste 4 săptămâni sunt variate; sunt enumerate în tabelul 1. În această perioadă, pot apărea simptome noi sau vor persista cele prezente din etapa anterioară. Timpul de recuperare variază; în majoritatea cazurilor, simptomele se remit în 12 săptămâni [3]. Probabilitatea de a dezvolta infecție cu SARS-CoV-2 simptomatic persistentă sau sindromul postCOVID-19 nu este legată de severitatea episodului acut de COVID-19. Se recomandă evaluarea clinică de către medicul de familie după 4 săptămâni de la debutul bolii, în vederea stabilirii semnelor și simptomelor care necesită evaluare paraclinică suplimentară sau doar monitorizare activă ulterioară prin teleconsultație. 
TABEL 1. Cele mai frecvente simptome în perioada postCOVID-19 acut

\author{
Fatigabilitate \\ Dificultăți în respirație \\ Tuse \\ Dureri articulare/musculare \\ Dureri toracice \\ Cefalee \\ Febră intermitentă \\ Palpitații \\ Anosmie, ageuzie \\ Tulburări de somn \\ Erupții cutanate \\ Căderea părului \\ Dificultăți de gândire și concentrare \\ Anxietate, depresie
}

În mai multe studii observaționale, au fost raportate simptome persistente la pacienții care au avut COVID-19 acut la peste o treime dintre pacienți, în proporție diferită: fatigabilitate (15-87\%), dispnee (10-71\%), durere toracică (12-44 \%), tuse (17-26\%). Simptomele mai puțin frecvente sunt reprezentate de: anosmie, dureri articulare, cefalee, sindrom sicca, rinită, disgeuzie, anorexie, vertij, mialgii, insomnie, alopecie, transpirații și diaree [3,15-17].

Prevalența tulburărilor de comportament și afectarea cognitivă este mai mare decât la cei care se recuperează după alte infecții virale [18]. Aproape jumătate dintre supravietuitorii COVID-19 au raportat scăderea calității vieții [15], 22\% au prezentat atacuri de panică/ anxietate/depresie [19]. Un sfert dintre pacienți prezintă simptomatologie anxios-depresivă persistentă la trei luni după debutul bolii [16].

$\mathrm{Au}$ fost publicate studii referitoare la efectele pe termen mediu ale infecției COVID-19 asupra mai multor organe precum cordul, plămânii, ficatul, rinichii, creierul.

Frecvența leziunilor cardiace în rândul pacienților spitalizați cu boală acută COVID-19 este estimată la 13$41 \%$ [20]. Sunt implicate mecanisme multiple ce determină apariția leziunilor cardiace, precum ischemia, hipoxia sistemică, tromboza, afectarea endoteliului și miocardita [20]. Leziunile cardiovasculare cauzate de COVID-19 la copii și adolescenți sunt mult mai puțin frecvente decât cele observate la adulți și includ un sindrom inflamator multisistem (MIS-C), cu leziuni de miocardită, pericardită și anevrisme arteriale [20,21].

Examinarea clinică cardiopulmonară poate evidenția fibroză pulmonară, revărsat pleural, prezența suflurilor cardiace, frecătură pericardică, zgomote cardiace supraadăugate, jugulare turgescente, raluri crepitante fine, bazal, bilateral sau prezența edemului periferic $[16,17,19,20]$.

În perioada de recuperare a pacienților cu COVID-19 cu simptome cardiopulmonare, se recomandă efectuarea unei radiografii toracice și a electrocardiogramei după 4 săptămâni, în special dacă nu au fost efectuate în perioada acută. Investigațiile suplimentare, precum ecocardiografia, monitorizarea Holter, monitorizarea ambulatorie automată a tensiunii arteriale (MAATA) și testele funcției respiratorii sunt necesare doar la pacienții care prezintă angor de novo, agravarea dispneei, agravarea insuficienței cardiace, valori tensionale necontrolate terapeutic $[19,20]$.

Pentru orice pacient cu simptome respiratorii sau cardiace inexplicabile după evaluarea inițială cardiopulmonară, inclusiv evaluarea bolii tromboembolice venoase, precum și la pacienții care au fost spitalizați cu COVID-19 acut, se recomandă testul de mers pe jos timp de șase minute $[17,19,20]$.

Paciențiilor cu complicații neurologice ale COVID-19 acut (de exemplu, accident vascular cerebral, convulsii, encefalopatie hipoxică, sindrom Guillain-Barré, encefalită, sindrom de decondiționare), se recomandă efectuarea examenului neurologic complet, evaluarea gradului de deficit rezidual și impactul acestora asupra stării funcționale a pacientului [22].

Se recomandă evaluarea clinică și paraclinică a tuturor pacienților pentru semne și simptome de tromboze venoase profunde (TVP) ale extremităților superioare și inferioare, embolie pulmonară sau tromboze arteriale (de exemplu, ischemie digitală). Pentru pacienții care au tratament anticoagulant, se reevaluează durata și indicațiile pentru tratamentul anticoagulant [23].

La pacienții care au avut disfuncție renală și hepatică în timpul infecției acute cu SARS-CoV-2, se recomandă evaluarea hipertensiunii arteriale, anemiei, precum și funcția hepatică și cea renală. Procentul celor care prezintă disfuncție renală sau hepatică pe termen lung este mic [24].

În timpul bolii acute COVID-19, pacienții cu diabet zaharat de tip 2 pot deveni insulino-necesitanți; acest lucru impune evaluarea atentă a glicemiei și HbA1c, ulterior, în timpul perioadei de recuperare [25].

Tulburările de somn după COVID-19 acut sunt frecvente, ceea ce impune evaluarea calității și duratei somnului la fiecare examinare clinică. Toți pacienții cu tulburări de somn vor fi evaluați și vor primi consiliere cu privire la igiena somnului, tehnici de relaxare și controlul stimulilor [26].

\section{CONCLUZII}

Procesul de recuperare după infecția cu virusul SARS-CoV-2 este complex, continuu și are ca scop identificarea și gestionarea complicațiilor asociate în perioada acută a bolii COVID-19, dar și monitorizarea ulterioară a simptomelor persistente ulterior fazei acute. Monitorizarea ulterioară variază de la o săptămână pănă la trei luni, în funcție de simptomatologia și factorii de risc prezenți. În timpul evaluării inițiale de urmărire, obținem un istoric cuprinzător al bolii COVID-19 a 
pacientului, incluzând cronologia bolii, durata și severitatea simptomelor, tipurile și severitatea complicațiilor. Necesitatea testelor de laborator este determinată de

Conflict of interest: none declared

Financial support: none declared severitatea bolii, de rezultatele anterioare în timpul bolii lor și de prezența și intensitatea simptomelor actuale.

\section{BIBLIOGRAFIE}

1. https://covid19.who.int/ - accesat 01.03.2021.

2. https://www.ecdc.europa.eu/en/covid-19/ accesat 01.03.2021.

3. https://www.nice.org.uk/guidance/ng188 COVID-19 rapid guideline: managing the long-term effects of COVID-19 - accesat 26 februarie 2021

4. Diaconu C. A novel coronarovirus threatens the world. Arch Balk Med Union. 2020; 55(1):11-13.

5. Gheorghe $\mathrm{G}$ et al. The Infection with new coronavirus SARS-CoV-2. Ro J Med Pract. 2020;15(1):28-32.

6. Livingston $\mathrm{E}$, Bucher K. Coronavirus disease 2019 (COVID-19) in Italy. JAMA. 2020; 323(14):1335.

7. Oran DP, Topol EJ. The Proportion of SARS-CoV-2 Infections That Are Asymptomatic: A Systematic Review. Ann Intern Med. 2021 Jan 22:M20-6976.

8. Lu X, Zhang L, Du H, Zhang J, Li YY, Qu J, Zhang W, Wang $Y$, et al.; Chinese Pediatric Novel Coronavirus Study Team. SARSCoV-2 Infection in Children. N Engl J Med. 2020 Apr 23;382(17):1663-1665.

9. Ludvigsson JF, Systematic review of COVID-19 in children shows milder cases and a better prognosis than adults. Acta Paediatr. 2020;109:1088-1095.

10. Liu K, Fang YY, Deng Y, et al. Clinical characteristics of novel coronavirus cases in tertiary hospitals in Hubei Province. Chin Med J (Engl). 2020;133:1025.

11. Stokes EK, Zambrano LD, Anderson KN, et al. Coronavirus Disease 2019 Case Surveillance - United States, January 22-May 30, 2020. MMWR Morb Mortal Wkly Rep. 2020;69:759.
12. Tong JY, Wong A, Zhu D, Fastenberg JH, Tham T. The Prevalence of Olfactory and Gustatory Dysfunction in COVID-19 Patients: A Systematic Review and Meta-analysis. Otolaryngol Head Neck Surg. 2020 Jul;163(1):3-11.

13. Lechien JR, Chiesa-Estomba CM, Hans S, et al. Loss of Smell and Taste in 2013 European Patients With Mild to Moderate COVID-19. Ann Intern Med 2020;173:672.

14. Boscolo-Rizzo P, Borsetto D, Fabbris C, Spinato G, Frezza D, Menegaldo A, Mularoni F, Gaudioso P, et al. Evolution of Altered Sense of Smell or Taste in Patients With Mildly Symptomatic COVID-19. JAMA Otolaryngol Head Neck Surg. 2020 Jul 2;146(8):729-32

15. Carfi A, Bernabei R, Landi F, Gemelli Against COVID-19 Post-Acute Care Study Group. Persistent Symptoms in Patients After Acute COVID-19. JAMA 2020;324:603.

16. Xiong Q, Xu M, Li J, et al. Clinical sequelae of COVID-19 survivors in Wuhan, China: a single-centre longitudinal study. Clin Microbiol Infect. 2021;27:89.

17. Goërtz YMJ, Van Herck M, Delbressine JM, et al. Persistent symptoms 3 months after a SARS-CoV-2 infection: the post-COVID-19 syndrome? ERJ Open Res. 2020 Oct;6(4):00542-2020.

18. Taquet M, Luciano S, Geddes JR, Harrison PJ. Bidirectional associations between COVID-19 and psychiatric disorder: retrospective cohort studies of 62354 COVID-19 cases in the USA. Lancet Psychiatry 2021;8:130.

19. Wong AW, Shah AS, Johnston JC, Carlsten $C$, Ryerson CJ. Patient-reported outcome measures after COVID-19: a prospective cohort study. Eur Respir J. 2020 Nov 26;56(5):2003276.

20. Friedrich MG, Cooper Jr. LJ. What we (don't) know about myocardial injury after COVID-19. European Heart Journal 2021; ehab145.

21. https://www.cnscbt.ro/index.php/evaluarede-risc/1729-ecdc-rra-paediatricinflammatory-multisystem-syndrome-andsars-cov-2-infection-in-children/file.

22. Price DR, Mikkelsen ME, Umscheid CA, Armstrong EJ. Neuromuscular Blocking Agents and Neuromuscular Dysfunction Acquired in Critical IIIness: A Systematic Review and Meta-Analysis. Crit Care Med. 2016 Nov;44(11):2070-2078.

23. Spruit MA, Holland AE, Singh SJ, Tonia T, Wilson KC, Troosters T. COVID-19: Interim Guidance on Rehabilitation in the Hospital and Post-Hospital Phase from a European Respiratory Society and American Thoracic Society-coordinated International Task Force. Eur Respir J. 2020 Aug 13; 56(6):2002197.

24. Shah W, Hillman T, Playford ED, Hishmeh L. Managing the long term effects of COVID-19: summary of NICE, SIGN, and RCGP rapid guideline. BMJ. 2021;372:n136.

25. Rubino F, Amiel SA, Zimmet P, Alberti G, Bornstein S, Eckel RH, Mingrone G, et al. New-Onset Diabetes in Covid-19. N Engl J Med. 2020 Aug 20;383(8):789-790.

26. Greenhalgh T, Knight M, A'Court C, Buxton M, Husain L. Management of post-acute covid-19 in primary care. BMJ. 2020 Aug 11;370:m3026. 